
ISSN : 2615-1995, E-ISSN : 2615-0654

J. Madani., Vol. 3, No. 1, Maret 2020 (33 - 41)

C2018 Lembaga Kajian Demokrasi

dan Pemberdayaan Masyarakat (LKD-PM)

DOI : https://doi.org/10.33753/madani.v3i1.85

\title{
Pengaruh Kebijakan Potongan Harga Terhadap Penjualan Pada PT Dunia Bangunan BSD
}

\author{
Dede Abdurohman \\ Fakultas Ekonomi, Universitas Pamulang \\ dosen02402@unpam.ac.id
}

\begin{abstract}
Abstrak
Tujuan penulisan ini adalah untuk mengetahui pengaruh kebijakan potongan harga terhadap penjualan dan untuk mengetahui peningkatan penjualan bahan bangunan pada PT. Dunia Bangunan BSD. Pada metode ini, metode yang digunakan adalah metode deskriptif kuantitatif yaitu data yang dinyatakan dalam bentuk angka, dimulai dari pengumpulan data, penafsiran data tersebut, serta penafsiran dari hasil yang bersifat data. Data yang digunakan adalah data primer dan data sekunder. Data primer adalah data yang diperoleh dan dikumpulkan langsung oleh orang yang melakukan penelitian di lapangan atau yang bersangkutan yang memerlukannya. Data primer dalam penelitian ini adalah data tentang PT. Dunia Bangunan BSD serta hasil wawancara dengan pihak terkait, sedangkan data sekunder adalah data yang diolah lebih lanjut menjadi bentuk-bentuk seperti table, grafik, diagram dan sebagainya sehingga lebih informatif oleh pihak lain. Data sekunder dalam hal ini adalah buku-buku dan media online. Hasil penelitian menunjukkan selama lima tahun perusahaan mengalami peningkatan penjualan. Berdasarkan analisis korelasi dapat disimpulkan bahwa $r=$ 0,910. Hal ini menunjukan bahwa adanya hubungan positif atau sangat kuat antara potongan harga (X) dan volume penjualan (Y). dari $r=0,910$ maka koefisien determinasi sebesar $(0,910) 2 \times 100 \%=82,81 \%$, hal ini menunjukkan bahwa adanya kointribusi potongan harga dalam meningkatkan volume penjualan pada PT. Dunia Bangunan BSD sebesar 82,81\%, sedangkan selebihnya 17,91\% dipengaruhi oleh faktor lain yang tidak diamati.
\end{abstract}

Kata Kunci : Potongan Harga, Penjualan

\begin{abstract}
The purpose of this paper is to determine the effect of discounting policies on sales and to determine the increase in sales of building materials at PT. BSD Building World. In this method, the method used is quantitative descriptive method that is data expressed in the form of numbers, starting from data collection, interpretation of the data, and interpretation of the results that are data. The data used are primary data and secondary data. Primary data is data obtained and collected directly by people doing research in the field or those who need it. Primary data in this study are data about PT. BSD Building World and the results of interviews with related parties, while secondary data is data that is further processed into forms such as tables, graphs, diagrams and so on so that it is more informative by other parties. Secondary data in this case are books and online media. The results of the study show that for five years the company experienced an increase in sales. Based on the correlation analysis it can be concluded that $r=0.910$. This shows that there is a positive or very strong relationship between price cuts $(X)$ and sales volume $(Y)$. of $r=0.910$, the coefficient of determination of $(0.910) 2 \times 100 \%=82.81 \%$, this shows that there is a discounted cointribution in increasing sales volume at PT. World's Buildings BSD of $82.81 \%$, while the remaining $17.91 \%$ is influenced by other factors not observed.
\end{abstract}

Keywords : Discounted Prices, Sales. 


\section{PENDAHULUAN}

Pertumbuhan perekonomian di Indonesia dewasa ini semakin terlihat semakin pesat, begitu juga dengan pertumbuhan barang dan jasa oleh konsumen yang juga lebih pesat lagi. Oleh karena itu, perusahaan-perusahaan di Indonesia saling berpacu agar dapat bersaing dalam memenuhi kebutuhan konsumennya dengan cara menghasilkan suatu barang dan jasa sesuai dengan keinginan konsumen yang semakin lama semakin pintar dalam memilih barang dan jasa sesuai dengan kebutuhannya dengan cermat dan tepat yang semakin membuat perusahaan semakin sulit untuk menawarkan barangnya kepada konsumen secara langsung tanpa menggunakan metode-metode yang baik dan tepat agar sesuai dengan arah sasaran. Hal ini mengakibatkan munculnya persaingan antar perusahaan, khususnya perusahaan-perusahaan yang menghasilkan barang dan jasa yang sejenis. Keadaan seperti ini membuat setiap perusahaan memikirkan untuk memilih strategi pemasaran yang baik, tepat sasaran dan dapat diterima oleh konsumen untuk mengatasi hal tersebut. Oleh karena itu, pemasaran merupakan salah satu kegiatan yang harus dilakukan dalam menghadapi persaingan, untuk mengembangkan usaha dan untuk mendapatkan laba/keuntungan, sehingga perusahaan dapat mengembangkan produk-produknya, menetapkan harga, mengadakan promosi, dan mendistribusikan barang dan jasa dengan efektif.

Dalam hal ini ditempat saya bekerja ada sedikit kendala mengenai pemasaran yang membuat saya terpacu untuk melakukan penelitian di PT Dunia Bangunan BSD untuk kebaikan perusahaan agar perusahaan bisa lebih berkembang dan maju karena apabila perusahaan dapat bertahan dan mungkin juga maju impact secara langsung maupun tidak langsung akan terasa oleh karyawan. Dan saya akan mulai dari memperkenalkan perusahaan dimana tempat saya bekerja yaitu PT Dunia Bangunan BSD, dimana perusahaan ini berdiri atau tepatnya Grand Opening tanggal 19 Februari 2009, alamat tepatnya di jalan Pahlawan Seribu BSD Junction dan PT Dunia Bangunan BSD ini bergerak dibidang Retail bahan bangunan yang dimiliki oleh Bapak Ir. Hardani Kawilarang sebagai Owner dan Juga Manajemennya. Dalam perjalanan waktunya memang perusahaan ini berkembang tetapi belakangan terakhir ini terlihat banyak kendala yang datang silih berganti mulai dari sumber daya manusianya sampai dengan pemasaran.

Karena saya mengambil studi jurusan Manajemen Pemasaran maka saya akan coba fokuskan penelitian kepada permasalahan pemasarannya dimana pemasaran juga sangat vital untuk keberlangsungan jalannya perusahaan maka dari itu kegiatan pemasaran merupakan salah satu kegiatan yang dijalankan oleh perusahaan untuk memasarkan dan menjual barang dagangannya kepada konsumen. Kegiatan pemasaran yang dilakukan perusahaan harus dapat memberikan kepuasan kepada konsumen. Menurut Philip Kotler dalam bukunya "Principle of Marketing", pengertian pemasaran adalah kegiatan manusia yang diarahkan kepada usaha yang memuaskan kebutuhan dan keinginan melalui proses pertukaran. Sehingga dapat dikatakan bahwa pemasaran memegang peranan penting dalam menunjang kegiatan perusahaan-perusahaan di dalam meningkatkan penjualan.

Peranan pemasaran dalam keberhasilan perusahaan telah diakui dikalangan pengusaha untuk mempertahankan keberadaannya dalam mengembangkan usaha dan mendapatkan keuntungan. Salah satu ukuran keberhasilan perusahaan tersebut adalah dengan diperolehnya laba melalui peningkatan volume penjualan. Agar tujuan perusahaan untuk meningkatkan hasil penjualan tercapai maka, perusahaan harus mampu mempunyai cara-cara atau metode-metode yang digunakan sebagai pedoman terutama dalam bidang pemasaran. Strategi pemasaran adalah cara yang paling tepat dalam upaya meningkatkan penjualan. Caranya adalah dengan menetapkan harga, promosi serta saluran distribusi barang dan jasa yang dapat memberikan kepuasan kepada konsumen.

Harga merupakan salah satu penentu keberhasilan suatu perusahaan karena menentukan seberapa besar keuntungan yang akan diperoleh perusahaan dari penjualan produknya, baik 
berupa barang maupun jasa. Harga juga salah satu elemen bauran pemasaran yang paling fleksibel, harga dapat diubah dengan cepat, tidak seperti ciri khas (feature), produk dan perjanjian distribusi (Philip Kotler: 2018). "Setiap perusahaan berusaha menetapkan harga yang paling tepat, supaya dapat memberikan keuntungan yang di harapkan".

Dalam kegiatan pemasaran ada unsur -unsur yang dinamakan dengan bauran promosi yaitu periklanan, publisitas dan humas, pemasaran langsung, promosi penjualan dan penjualan tatap muka. Promosi pada hakekatnya adalah suatu komunikasi pemasaran artinya aktivitas pemasaran yang berusaha menyebarkan informasi, mempengaruhi/membujuk, dan atau mengingatkan pasar sasaran atas perusahaan dan produknya agar bersedia menerima, membeli dan loyal pada produk yang ditawarkan perusahaan yang bersangkutan, Tjiptono (2008: 219).

Salah satu alat dari promosi penjualan adalah potongan harga, potongan harga adalah pengurangan harga produk dari harga normal dalam periode tertentu. Maka dari itu dari berbagai strategi tersebut, promosi dan kebijakan harga yang dalam hal ini adalah pemberian potongan harga, merupakan bagian yang penting serta berpengaruh terhadap peningkatan penjualan. Dalam kebijakan penetapan harga para pembuat keputusan dalam perusahaan harus mempertimbangkan reaksi dari berbagai pihak, baik yang berasal dari dalam perusahaan maupun yang dari luar perusahaaan yang dapat mempengaruhi atau sebaliknya mempengaruhi oleh keputusan mengenai harga yang ditetapkan. Kegiatan promosi yang berupa potongan harga akan dapat menambah serta mempengaruhi konsumen terhadap nilai barang atau jasa yang sedang diedarkan di pasaran. Dengan adanya kegiatan tersebut akan mendorong dan mengarahkan konsumen untuk membeli, sehingga penjualan akan meningkat sesuai dengan tujuan yang diharapkan. Selain itu, pemberian potongan harga kepada konsumen akan dapat menambah dan mempertahankan minat konsumen untuk melakukan pembelian terhadap produk yang ditawarkan oleh perusahaan.

Dalam hal tersebut, pengetahuan akan bauran pemasaran yangbaik dalam upaya pelaksanaan kegiatan pemasaran secara intensif menjadi faktor penting yang harus diketahui oleh perusahaan dalam upaya mempertahankan kelangsungan hidup perusahaan dan menjangkau konsumen sebanyak-banyaknya. Sehingga berbagai kajian yang dilakukan perusahaan untuk meningkatkan penjualan melalui kebijakan potongan harga akan mendapatkan tanggapan yang positif dari konsumen agar dapat mencapai laba dan tujuan yang diharapkan oleh perusahaan.

Berdasarkan hal tersebut, maka penulis tertarik untuk mengambil judul dalam skripsi ini yaitu tentang "Pengaruh Kebijakan Potongan Harga Terhadap Penjualan Pada PT Dunia Bangunan BSD”.

\section{Pembatasan Masalah}

Berdasarkan uraian di atas, untuk memudahkan pemahaman yang kurang tepat, maka penulis melakukan pembatasan-pembatasan masalah sebagai berikut. Kebijakan potongan harga adalah pengurangan harga produk dari harga normal dalam periode tertentu. Sumber: Sutisna, dalam bukunya yang berjudul Perilaku Konsumen dan Komunikasi Pemasaran (2001: 303). Penjualan adalah suatu kegiatan yang ditujukan untuk mencari pembeli, mempengaruhi, dan member petunjuk agar pembeli dapat menyesuaikan kebutuhannya dengan produksi yang ditawarkan serta mengadakan perjanjian mengenai harga yang menguntungkan bagi kedua belah pihak. Sumber: Moekijat dalam bukunya Kamus Manajemen Cetakan ke lima (2000: 48). Objek penelitian ini pada PT Dunia Bangunan BSD tepatnya pada perusahaan yang bergerak pada bidang retail bahan bangunan.

\section{METODE}

Penelitian ini dilakukan pada PT. Dunia Bangunan BSD yang merupakan suatu perusahaan yang bergerak dibidang perdagangan bahan bangunan lebih tepatnya lagi bisa disebut retail bahan bangunan. Penelitian ini bersifat deskriftif kuantitatif, yaitu data yang dinyatakan dalam bentuk angka, dimulai dari penyimpulan data, 
penafsiran data tersebut, serta penampilan dari hasil yang bersifat data (Suharsimi Arikanto, 2013: 12).

Penulis melakukan penelitian pada perusahaan ini didasari oleh beberapa hal, antara lain: PT Dunia Bangunan BSD adalah perusahaan yang sedang berkembang pesat untuk perdagangan retail bahan bangunan diarea BSD. Produk yang diperdagangkan berupa bahan-bahan bangunan seperti Tile and Granit, Sanitary, Cat. Tool, Houseware, Elektrik. Sumber data

Sumber data yaitu keterangan yang benar dan nyata, yang dapat dijadikan kajian analisis atau kesimpulan dalam penelitian. Sumber data dalam penelitian ini adalah data primer dan data sekunder. Data primer adalah data yang diperoleh atau dikumpulkan langsung dilapangan oleh orang yang melakukan penelitian atau yang bersangkutan yang memerlukannya (Hasan, 2013: 82). Data primer dalam penelitian ini adalah data tentang PT. Dunia Bangunan serta hasil wawancara dengan pihak terkait. Data sekunder adalah data yang diolah lebih lanjut menjadi bentuk-bentuk seperti tabel, grafik, diagram dan sebagainya sehingga lebih informatif oleh pihak lain (Umar, :2002: 84). Dalam hal ini penulis menggunakan data sekunder berupa buku-buku dan media online. Buku-buku dan media online yang memuat informasi mengenai topik pembahasan yang penulis angkat dalam penelitian ini.

Teknik Pengumpulan data Penulis melakukan penelitian langsung ke perusahaan yang diteliti dengan menggunakan metode sebagai berikut: Observasi Menurut Sugiono (2005: 64) "observasi adalah dasar semua ilmu pengetahuan“. Para ilmuwan hanya dapat bekerja berdasarkan data yaitu fakta mengenai dunia kenyataan yang diperoleh melalui observasi. Dalam hal ini penulis melaksanakan pengamatan langsung terhadap PT Dunia Bangunan BSD. Dimana pengamatan terbatas pada pokok permasalahan saja sehingga fokus perhatian lebih tajam pada data yang lebih relevan dan peneliti melihat langsung pada objek penelitian dimana data yang telah diperoleh dapat digunakan untuk tambahan dalam melakukan analisis.
Kemudian wawancara digunakan sebagai teknik pengumpul data, apabila peneliti ingin melakukan penelitian di suatu perusahaan. Penulis datang keperusahaan guna mengadakan wawancara secara langsung dengan pihak yang berkompeten dalam perusahaan mengenai suatu objek yang diteliti. Wawancara yang digunakan adalah wawancara terbuka yang telah disediakan perusahaan untuk mendapatkan informasi tentang sejarah perusahaan, struktur organisasi, data tentang harga dan potongan harga, bidang usaha dan data penjualan.

Studi kepustakaan, penelitian kepustakaan dilakukan dengan mencari landasan teoritis yang berhubungan dengan judul penelitian guna memperoleh tentang Pengaruh Kebijakan Potongan Harga Terhadap Penjualan pada PT Dunia Bangunan BSD. Penelitian ini dilakukan dengan membaca berbagai buku dan literatur yang relevan dan mencari hubungan antara variabel yang diteliti sesuai dengan masalah yang ditemui.

\section{Metode Perhitungan dan Analisis Data}

Analisis data adalah proses mencari data dan menyusun secara sistematis data yang diperoleh melalui hasil wawancara, catatan lapangan, dokumentasi, dengan cara mengorganisasikan data ke dalam unit-unit, melakukan sintesa, menyusun dalam pola memilih mana yang penting dan akan dipelajari, dan membuat kesimpulan sehingga mudah dipahami oleh diri sendiri maupun orang lain (Sugiono, 2005: 89).

Salah satu metode analisis data yang lebih efisien dan efektif dalam hubungan tujuan riset adalah penggunaan teknik statistika, yaitu:

1. Koefisien korelasi dari pearson

Untuk mengetahui bagaimana hubungan antara potongan harga dengan penjualan, digunakan koefisiensi korelasi yang dirumuskan sebagai berikut:

$$
r=\frac{n\left(\sum \mathrm{xy}\right)-\left(\sum \mathrm{x}\right)\left(\sum \mathrm{y}\right)}{\sqrt{n\left(\sum \mathrm{x}^{2}\right)-\left(\sum \mathrm{x}\right)^{2} \cdot n\left(\left(\sum y^{2}\right)-\left(\sum \mathrm{y}\right)^{2}\right.}}
$$

Keterangan:

$\mathrm{r}=$ koefisiensi korelasi antara $\mathrm{x}$ dan $\mathrm{y}$

$\mathrm{n}$ = banyak data

$\mathrm{x}=$ nilai variabel bebas, yaitu potongan harga 
$\mathrm{y}=$ nilai variabel terikat, yaitu penjualan.

Dengan ketentuan sebagai berikut:

a. Apabila nilai $r>0$

Hubungan antara $\mathrm{x}$ dan $\mathrm{y}$ merupakan hubungan yang positif, yaitu semakin besar nilai variabel x (bebas), dimana semakin besar pula pengaruhnya terhadap nilai variabel y (terikat), atau sebaliknya semakin kecil nilai variabel $\mathrm{x}$ (bebas), maka semakin kecil pula nilai variabel y (terikat).

b. Apabila nilai $\mathrm{r}<0$

Hubungan $x$ dan y merupakan hubungan negative, yaitu semakin kecil nilai variabel x (bebas), maka semakin besar nilai variabel y (terikat) atau sebaliknya semakin besar nilai variabel x (bebas), maka semakin kecil nilai variabel y (terikat).

c. Apabila nilai $r=0$

Artinya antara variabel $\mathrm{x}$ dan $\mathrm{y}$ tidak terdapat huabungan sama sekali, variabel $\mathrm{x}$ (bebas) tidak member kontribusi terhadap peningkatan variabel y (terikat).

d. Apabila $r=1$ atau $r=-1$

Artinya telah telah terjadi hubungan sempurna antara variabel $\mathrm{x}$ (bebas) dan variabel y (terikat). Untuk $r=1$ berarti terdapat hubungan positif yang sempurna antara variabel $\mathrm{x}$ dengan variabel $y$, dan sebaliknya apabila $r=-1$ berarti terdapat hubungan negatif yang sempurna antara variabel $\mathrm{x}$ dengan variabel y.

\begin{tabular}{|c|c|}
\hline Tabel 1. Pedoman Interval Nilai Koefisien Korelasi dan Tingkat Hubungan \\
\hline Internal Koefisien Korelasi & Tingkat Hubungan \\
\hline $0.000-0.199$ & Sangat Rendah \\
\hline $0.200-0.399$ & Rendah \\
\hline $0.400-0.599$ & Cukup Kuat \\
\hline $0.600-0.799$ & Kuat \\
\hline $0.800-1.000$ & Sangat Kuat \\
\hline
\end{tabular}

2. Koefisien determinasi

Koefisien determinasi adalah uji ketepatan pikiran dilakukan untuk mendeteksi ketepatan paling baik dari garisregresi. Uji ini dilakukan dengan melihat besarnya nilai koefisien determinasi (KD) merupakan besaran nol negatif

Besarnya nilai koefisien determinasi adalah antara nol sampai dengan satu. Koefisien determinasi bernilai nol berarti tidak ada hubungan antara variabel $\mathrm{x}$ (bebas) dengan variabel y (terikat), sebaliknya nilai koefisien determinasi satu berarti suatu kecocokan sempurna dari ketetapan pertukaran model.

Sedangkan untuk mengetahui besarnya kontribusi dari nilai $\mathrm{x}$ terhadap nilai $\mathrm{y}$ dapat dihitung suatu koefisien yang disebut koefisien penentuan (coefficient of determination). Yang dirumuskan sebagai berikut:

$\mathrm{KD}=\mathrm{r}^{2} \mathrm{x} 100 \%$

Keterangan:

$\mathrm{KD}=$ Koefisien determinasi

$\mathrm{r} \quad=$ Koefisien korelasi antara $\mathrm{x}$ dan $\mathrm{y}$

Besar kecilnya nilai koefisien determinasi ini menunjukan besar kecilnya kontribusi atau sumbangan variabel bebas $(\mathrm{x})$ terhadap variabel terikat $(y)$.

3. Uji signifikan koefisiensi korelasi (uji - t)

Menurut j. Suprianto dan Yuni Astuti (2008: 6), uji signifikasi koefisien korelasi adalah menguji kuat lemahnya hubungan antara variabel. Rumus uji t untuk korelasi adalah:

Dengan menggunakan uji searah atas maka kriteria uji:

Thitung $=\frac{r \sqrt{n-2}}{\sqrt{1-r^{2}}}$

a. Jika $\mathrm{T}_{\text {hitung }}<\mathrm{t}_{\text {tabel }}$, berarti $\mathrm{H}^{0}$ diterima

b. Jika $\mathrm{T}_{\text {hitung }}>\mathrm{t}_{\text {tabel }}$ Berarti $\mathrm{H}^{0}$ ditolak interpretasi taraf signifikasi (j. Supranto, statistik 2, 2000)

c. Apabila $\mathrm{T}_{\text {hitung }}>\mathrm{t}_{\text {tabel }}$ pada taraf signifikasi $1 \%$ berarti hubungan antara variabel sangat signifikan

d. Apabila $\mathrm{T}_{\text {hitung }}<\mathrm{t}_{\text {tabel }}$ Pada taraf signifikasi $5 \%$ berarti hubungan antara variabel signifikan. 


\section{HASIL dan PEMBAHASAN}

Hasil

Dalam pelaksanaan di lapangan, penetapan harga bukan hanya berpengaruh bagi kelangsungan perusahaan itu sendiri tetapi juga bagi konsumen. Oleh karena itu, dalam menetapkan harga sebaiknya perusahaan mempertimbangkan pemberian potongan harga atau diskon yang di berikan kepada konsumen agar memiliki nilai manfaat bagi konsumen dan dapat memberikan manfaat bagi keuntungan perusahaan. PT. Dunia Bangunan 2 BSD yang bergerak pada bidang perdagangan retail bahan bangunan tentunya telah mempertimbangkan potongan harga yang ditetapkan untuk meningkatkan penjualannya. Berikut ini adalah hasil dan membahas mengenai seberapa besar pengaruh kebijakan potongan harga guna meningkatkan penjualan bahan bangunan pada PT Dunia Bangunan 2 BSD.

\section{Data Perusahaan}

PT Dunia Bangunan $2 \mathrm{BSD}$ adalah perusahaan yang sedang berkembang dan memiliki dua toko yaitu: di Daan Mogot dan di BSD. Perusahaan yang bergerak dalam bidang perdagangan retail bahan bangunan ini dilakukan secara cash atau kredit telah mampu manghadapi persaingan yang semakin ketat dan kompetitif. Hal ini dibuktikan dengan hasil penjualan setiap tahunnya yang meningkat.

Berikut ini adalah data hasil penjualan bahan bangunan yang disajikan dalam bentuk tabel pada PT Dunia Bangunan BSD:

Tabel 2. Total Penjualan PT. Dunia Bangunan BSD (Dalam Ribuan Rupiah)

\begin{tabular}{|c|c|c|c|c|}
\hline Model & Tahun & Total Transaksi & Total Unit & Total Penjualan \\
\hline 1 & 2010 & 246.556 & 537.122 & 32.056 .780 .438 \\
\hline 2 & 2011 & 294.741 & 626.773 & 39.920 .214 .992 \\
\hline 3 & 2012 & 336.964 & 716.373 & 47.861 .266 .723 \\
\hline 4 & 2013 & 346.530 & 757.445 & 57.707 .358 .221 \\
\hline 5 & 2014 & 381.085 & 1.144 .395 & 90.664 .743 .861 \\
\hline
\end{tabular}

Berdasarkan tabel di atas menunjukkan bahwa dari tahun 2010 sampai dengan tahun 2014 total unit yang dijual mengalami peningkatan sehingga total penjualan pun ikut meningkat.

Sedangkan prosentase penjualan bahan bangunan pada PT Dunia Bangunan BSD selama lima tahun adalah sebagai berikut:

Tabel 3. Prosentase Penjualan PT. Dunia Bangunan BSD
(Dalam Ribuan Rupiah)
\begin{tabular}{|c|c|c|c|c|}
\hline Model & Tahun & Total Penjualan & Kenaikan & $\%$ \\
\hline 1 & 2010 & 32.056 .780 .438 & - & - \\
\hline 2 & 2011 & 39.920 .214 .992 & 7.863 .434 .554 & 19.70 \\
\hline 3 & 2012 & 47.861 .266 .723 & 7.941 .051 .731 & 16.59 \\
\hline 4 & 2013 & 57.707 .358 .221 & 9.846 .091 .498 & 17.06 \\
\hline 5 & 2014 & 90.664 .743 .861 & 32.957 .385 .640 & 36.35 \\
\hline
\end{tabular}

Dari tabel di atas dapat dijelaskan bahwa terjadi kenaikan pada total penjualan atau kenaikan pada penjualan pada PT. Dunia Bangunan BSD, Yaitu pada tahun 2011 total penjualan mengalami kenaikkan Rp7.863.434.554 atau 19,70\% dari Rp32.056.780.438 menjadi Rp39.920.214.992. Pada tahun 2012 total penjualan mengalami kenaikan kembali yaitu Rp7.941.051.731 atau $16,59 \%$ dari Rp39.920.214.992 menjadi Rp47.861.266.723. Ditahun 2013 perusahaan mengalami kenaikan penjualan kembali sebesar Rp9.846.091.498 atau $17,06 \%$ dari Rp47.861.266.723 menjadi Rp57.707.358.221. Pada tahun 2014 juga penjualan mengalami kenaikan sebesar Rp.32.957.640 atau 36,35\% dari Rp57.707.358.221 menjadi Rp90.664.743.861.

Di bawah ini adalah data mengenai potongan harga atau diskon yang ditetapkan oleh PT. Dunia Bangunan BSD dalam lima tahun, yaitu:

\begin{tabular}{|c|c|c|c|c|}
\hline \multicolumn{5}{|c|}{$\begin{array}{l}\text { Tabel 4. Potongan Penjualan (Diskon) PT. Dunia Bangunan BSD } \\
\text { (Dalam Ribuan Rupiah) }\end{array}$} \\
\hline Model & Tahun & $\begin{array}{l}\text { Total Harga } \\
\text { Sebelum Diskon }\end{array}$ & Potongan Harga & Total Penjualan \\
\hline 1 & 2010 & 32.697 .916 .047 & 641.135 .609 & 32.056 .780 .438 \\
\hline 2 & 2011 & 40.718 .619 .292 & 798.404 .300 & 39.920 .214 .992 \\
\hline 3 & 2012 & 48.818 .492 .057 & 957.225 .334 & 47.861 .266 .723 \\
\hline 4 & 2013 & 58.861 .505 .385 & 1.154 .147 .164 & 57.707 .358 .221 \\
\hline 5 & 2014 & 92.478 .038 .738 & 1.813 .294 .877 & 90.664 .743 .861 \\
\hline
\end{tabular}

Berdasarkan tabel di atas menunjukkan besar kecilnya tingkat potongan harga yang diberikan juga mempengaruhi besar kecilnya total penjualan yang didapatkan. Hal ini terlihat dari tahun 2010 hingga tahun 2014 penjualan mengalami peningkatan yang dipengaruhi oleh peningkatan potongan harga yang diberikan pada tahun 2010 hingga tahun 2014. 
1. Perhitungan Analisis Data

Tabel 5. Perhitungan Potongan Harga (x) dengan penjualan (y)
(Dalam Milyaran Rupiah)
\begin{tabular}{|c|c|c|c|c|c|}
\hline Tahun & $\mathbf{x}$ & $\mathbf{y}$ & $\mathbf{x . y}$ & $\mathbf{x}^{2}$ & $\mathbf{y}^{2}$ \\
\hline 2010 & 641 & 32.057 & 20.548 .537 & 410.881 & 1.027 .651 .249 \\
\hline 2011 & 798 & 39.920 & 31.856 .160 & 636.804 & 1.593 .606 .400 \\
\hline 2012 & 957 & 47.861 & 45.802 .977 & 915.849 & 2.290 .675 .321 \\
\hline 2013 & 1.154 & 57.707 & 66.593 .878 & 1.331 .716 & 3.330 .097 .849 \\
\hline 2014 & 1.813 & 90.665 & 164.375 .645 & 3.286 .969 & 8.220 .142 .225 \\
\hline$\Sigma$ & 5.363 & 268.210 & 329.177 .197 & 6.582 .219 & 16.462 .173 .044 \\
\hline
\end{tabular}

\section{Pembahasan}

a. Analisis Korelasi

Rumus perhitungan korelasi adalah:

$$
r=\frac{n\left(\sum \mathrm{xy}\right)-\left(\sum \mathrm{x}\right)\left(\sum \mathrm{y}\right)}{\sqrt{n\left(\sum \mathrm{x}^{2}\right)-\left(\sum \mathrm{x}\right)^{2} \cdot n\left(\left(\sum y^{2}\right)-\left(\sum \mathrm{y}\right)^{2}\right.}}
$$

Dimana:

$\mathrm{r}$ : Koefisien Korelasi

$\mathrm{n}$ : Jumlah data yang dihitung

$\mathrm{x}$ : Potongan Harga

$\mathrm{y}:$ Penjualan

$$
\begin{aligned}
& r=\frac{n\left(\sum \mathrm{xy}\right)-\left(\sum \mathrm{x}\right)\left(\sum \mathrm{y}\right)}{\sqrt{n\left(\sum \mathrm{x}^{2}\right)-\left(\sum \mathrm{x}\right)^{2} \cdot n\left(\left(\sum y^{2}\right)-\left(\sum \mathrm{y}\right)^{2}\right.}} \\
& r=\frac{5(329.177 .197)-(5.363)(268.210)}{\sqrt{5(6.582 .219)-(5.363)^{2} \cdot 5\left((16.462 .173 .044)-(268.210)^{2}\right.}} \\
& r=\frac{1.645 .885 .985-1.438 .410 .230}{\sqrt{(32.911 .095-28.761 .769) \cdot(82.310 .865 .220-71.936 .604 .100)}} \\
& r=\frac{207.475 .755}{\sqrt{4.149 .326 \cdot 10.374 .261 .120}} \\
& r=\frac{207.475 .755}{\sqrt{43.046 .191 .386 .005 .160}} \\
& r=0,9999999711 \\
& r=0,910
\end{aligned}
$$

Berdasarkan perhitungan di atas, dapat disimpulkan bahwa $\mathrm{r}=0,910$ berarti telah terjadi hubungan positif atau tingkat hubungan yang sangat kuat antara variable $\mathrm{x}$ dengan variable y. apabila kebijakan potongan harga yang diberikan oleh perusahaan diterima dengan baik oleh pelanggan atas konsumen maka akan meningkat penjualannya.

b. Analisis Koefisien Determinasi

$$
\begin{aligned}
& \mathrm{KD}=\mathrm{r}^{2} \times 100 \% \\
& \mathrm{KD}=(0,910)^{2} \times 100 \% \\
& \mathrm{KD}=0,8281 \times 100 \%
\end{aligned}
$$

$\mathrm{KD}=82,81$

Nilai Koefisien Determinasi KD $=82,81 \%$ ini menunjukkan bahwa kontribusi potongan harga produk bahan bangunan terhadap penjualan pada PT. Dunia Bangunan BSD sebesar 82,81 sedangkan selebihnya yaitu $100 \%-82,81=17,91$ dipengaruhi oleh faktor lain. Faktor lain tersebut diantaranya bisa berupa promosi atau pameran-pameran yang biasanya terdapat harga yang lebih murah dari biasanya. Selain itu traffic showroom juga dapat menambah penjualan pada PT. Dunia Bangunan BSD.

c. Pengujian Hipotesis Dengan uji-t Untuk menguji signifikasi hubungan antara potongan harga dengan penjualan bahan bangunan pada PT. Dunia Bangunan BSD, maka perlu suatu uji koefisiensi korelasi yang ditunjukkan pada rumus sebagai berikut:

$$
\begin{aligned}
& \text { Thitung }=\frac{r \sqrt{n-2}}{\sqrt{1-r^{2}}} \\
& \text { Thitung }=\frac{0,910 \sqrt{5-2}}{\sqrt{1-0,910^{2}}} \\
& \text { Thitung }=\frac{0,910 \times 1,73}{\sqrt{1-0,83}} \\
& \text { Thitung }=\frac{1,5743}{\sqrt{0,17}} \\
& \text { Thitung }=\frac{1,57}{0,41} \\
& \text { Thitung }=\frac{1,57}{0,41} \\
& \text { Thitung }=3,82 \\
& \text { Thitung }=4
\end{aligned}
$$

Berdasarkan perhitungan di atas dimana $\mathrm{T}$ hitung $=4$ untuk kesalahan $5 \%$ dan DK = 5-4 = 1, Ttabel diperoleh sebesar 6,314. Jadi Thitung < Ttabel maka Ho diterima. Namun pada hitungan sebelumnya, yaitu pada uji korelasi dan determinasi terdapat hubungan yang positif atau sangat kuat antara potongan harga dan penjualan pada PT Dunia Bangunan BSD. 


\section{SIMPULAN}

Berdasarkan penelitian dari hasil pembahasan oleh penulis, maka dapat diambil kesimpulan sebagai berikut: PT. Dunia bangunan BSD melakukan kebijakan potongan harga selama lima tahun dari tahun 2010 sampai dengan tahun 2014. Pada tahun 2010 kebijakan harga ditetapkan sebesar Rp641.135.609,-dengan memperoleh hasil penjualan sebesar Rp32.056.780.438,- pada tahun 2011 potongan harga sebesar Rp798.404.300,dengan hasil penjualan Rp39.920.214.992,- tahun 2012 potongan harga sebesar $\mathrm{Rp} 957.225 .334$,- dan memperoleh hasil penjualan Rp47.861.266.723,berikutnya tahun 2013 potongan harga sebesar Rp1.154.147.164,- dan memperoleh hasil penjualan sebesar Rp57.707.358.221,- dan terakhir pada tahun 2014 potongan penjualan sebesar Rp1.813.294.877,- dengan memperoleh penjualan sebesar Rp90.664.743.861. Kebijakan potongan harga yang ditetapkan oleh PT. Dunia Bangunan BSD adalah dengan maksud untuk meningkatkan penjualan pada produknya, yaitu penjualan bahan bangunan. Hasil penelitian menunjukan selama lima tahun perusahaan mengalami peningkatan penjualan. Penjualan tahun 2010 adalah menjadi dasar tahun sehingga belum ada tingkat prosentase peningkatannya, pada tahun 2011 sampai tahun 2014 menjadi tahun berjalan atau current period dengan diperoleh angka kenaikan atau peningkatan penjualan pada tahun 2011 sebesar Rp7.863.434.554,- atau 19,70\% pada tahun 2012 penjualan mengalami kenaikan sebesar Rp7.941.051.731,- atau 16,59\% ditahun 2013 kenaikan penjualan sebesar Rp9.846.091.497,- atau 17,06\% dan pada tahun 2014 perusahaan mengalami peningkatan penjualan sebesar Rp32.957.384.640 atau 36,35\%. Terdapat pengaruh yang sangat kuat antara kebijakan potongan harga yang dilakukan dengan penjualan pada PT. Dunia Bangunan BSD pada bidang penjualan produk bahan bangunan. Kuatnya hubungan antara potongan harga dengan penjualan dapat dibuktikan dengan menggunakan metode ststistika korelasi sederhana menunjukkan nilai $r=0,910$ atau $(0,910) 2$ $=82,81 \%$ yang berarti dari perubahan atau peningkatan volume penjualan disebabkan oleh kebijakan potongan harga. Sedangkan sisanya 17,19 disebabkan oleh faktor lain yang tidak teramati dalam penelitian ini. Berdasarkan perhitungan di atas dimana $\mathrm{T}_{\text {hitung }}=4$ untuk kesalahan $5 \%$ dan $\mathrm{DK}=5-4=1, \mathrm{~T}_{\text {tabel }}$ diperoleh sebesar 6,314. Jadi $\mathrm{T}_{\text {hitung }}<\mathrm{T}_{\text {tabel }}$ maka Ho diterima. Namun pada hitungan sebelumnya, yaitu pada uji korelasi dan determinasi terdapat hubungan yang positif atau sangat kuat antara potongan harga dan penjualan pada PT. Dunia Bangunan BSD.

\section{PENGHARGAAN}

Pada kesempatan kali ini penulis ingin mengucapkan terimakasih kepada semua yang terlibat baik secara langsung maupun tidak langsung yang tidak bisa penulis sebutkan satu persatu. Terimakasih atas saran, masukan, dan bantuan, semoga penelitian ini bisa bermanfaat bagi semua pihak.

\section{DAFTAR PUSTAKA}

Assauri, S. (2018). Manajemen Pemasaran. Jakarta: Raja Grafindo.

Buchari, A. (2018). Manajemen Pemasaran dan Pemasaran Jasa. Bandung: Alfabeta.

Hasan, A. (2013). Marketing. Yogyakarta: Media Pressindo.

Ikbal, M. H. (2002). Pokok-pokok Materi Metodologi Penelitian dan Aplikasinya. Jakarta: Ghalia Indonesia.

Istijanto. (2009). Apliksi Praktis Riset Pemasaran, Cara Praktis Meneliti Konsumen dan Pesaing. Jakarta: Gramedia Pustaka Utama.

Khairul, M. (2010) http://ammarawita usaha. blogspot.com.

Kotler, P \& Amstrong, G. (2014). Prinsip - Prinsip Pemasaran. Jakarta: Erlangga.

Kotler, P \& Keller, L. K. (2018). Manajemen Pemasaran. Jakarta: Erlangga.

Lamarto, Y. (1999). Prinsip Pemasaran. Jakarta: Erlangga.

Saladin, D (2003) Intisari Pemasaran dan Unsurunsur Pemasaran. Bandung: Linda Karya.

Sexton, D. (2007). Trump University Marketing 101. Jakarta: Gramedia Pustaka Utama.

Suharsimi, A. (2013). Prosedur Penelitian Suatu 
Pendekatan Praktik. Jakarta: Rineka Cipta. Sugiono. (2005). Memahami Penelitian Kualitatif. Bandung: Alfabeta.

Sumarwan, U. (2002). Perilaku Konsumen. Jakarta: Ghalia Indonesia.

Sutoyo, S. (2009). Manajemen Pemasaran. Jakarta: Damar Mulia Pustaka.

Stanton, J. W. (1999). Fundamental of Marketing. Yogyakarta: Liberty.
Swasta, B \& Irawan. (2008). Manajemen Pemasaran Modern. Yogyakarta: Liberty.

Tim. Marknesis. (2009). Pemasaran Strategi, Taktik dan Kasus. Yogyakarta: Marknesis.

Tjiptono, F \& Fregorius, C \& Dadi, A. (2008). Pemasaran Strategi. Yogyakarta: Andi Offset.

Umar, H. (2002). Metodologi Riset Komunikasi Organisasi. Jakarta: Gramedia Pustaka Utama. 